\title{
TASOS1 AND TATM20 GENES EXPRESSION AND NUTRIENT UPTAKE IN WHEAT SEEDLINGS MAY BE ALTERED VIA EXCESS CADMIUM EXPOSURE AND INOCULATION WITH AZOSPIRILLUM BRASILENSE SP7 UNDER SALINE CONDITION
}

\author{
GHASSEMI, H. R. ${ }^{1}-$ MOSTAJERAN, A. ${ }^{2 *}$ \\ ${ }^{I}$ Department of Biology, University of Isfahan, Isfahan, Iran \\ ${ }_{2}^{2}$ Plant Science Division, Biology Department, University of Isfahan, Isfahan, Iran \\ (phone: +98-91-8335-0785; fax: +98-31-3793-2456) \\ *Corresponding author \\ e-mail: mostajerana@yahoo.com; phone: +98-31-3793-2471; fax: +98-31-3793-2456 \\ (Received $19^{\text {th }}$ Oct 2017; accepted 27 $7^{\text {th }}$ Feb 2018)
}

\begin{abstract}
Excess of salt and cadmium (Cd) damage the plant's growth; however, Cd toxicity is more severe under saline condition. Triticum aestivum transmembrane 20 (TaTM20) and salt overly sensitive (SOS) respond to salinity. Moreover, wheat-Azospirillum association system leads to an increase in wheat tolerance to abiotic stresses. Less information exists related to the effect of salinity and $\mathrm{Cd}$ under wheatAzospirillum associated system. Therefore, this experiment was conducted to evaluate the effect of Azospirillum-wheat association under salinity and/or Cd stresses. Wheat seedlings (Sardari cultivar) inoculated with Azospirillum brasilense Sp7and grown for five days, and then transferred into hydroponic media for five more days with and without $200 \mathrm{mmol} \mathrm{NaCl}$ and/or $50 \mathrm{mg} \mathrm{L}^{-1} \mathrm{Cd}$, respectively. Root and shoot samples were separated and then dry weight, proline, photosynthetic pigments, catalase (CAT) and ascorbate peroxidase (APX) activities, $\mathrm{Cd}, \mathrm{Fe}, \mathrm{Ca}, \mathrm{Na}, \mathrm{K}$ were measured. Simultaneously, relative expression of TaSOS1 and TaTM2O in the root were measured. The results show salinity and/or Cd have increased root's TaSOS1 expression and higher upregulation was seen in inoculated seedlings. Meanwhile TaTM20 gene expression upregulated only under $\mathrm{Cd}$ and $\mathrm{Cd}$ plus salinity conditions. Salinity and/or $\mathrm{Cd}$ were increased root and shoot proline, CAT, APX, $\mathrm{Na}^{+}$and $\mathrm{Cd}$ whereas dry weight, pigments, $\mathrm{Fe}, \mathrm{Ca}, \mathrm{K}$ were decreased. A. brasilense could improve salinity and $\mathrm{Cd}$ adverse effects by more upregulation of TaSOS1 transcript level, lower $\mathrm{Na} / \mathrm{K}$ ratio and less $\mathrm{Fe}$ and $\mathrm{Ca}$ deficiency, higher pigments, proline and APX and CAT activities to produce more dry weight.
\end{abstract}

Keywords: chlorophyll, carotenoid, $\mathrm{Fe}, \mathrm{Na}, \mathrm{K}$, dry weight

\section{Introduction}

A considerably large portion of arable land (estimated $20 \%$ of total cultivated and $33 \%$ of irrigated lands) in the world is affected by salinity (Nellemann, 2009). Furthermore, the salt affected lands are increasing 10\% annually due to the low precipitation, high surface evaporation, weathering of rocks, irrigation with saline water, and poor cultivation. It has been estimated that more than $50 \%$ of the arable land would be salinized by the year 2050 (Jamil, 2011). Salinity has inhibitory effects on crop production (such as wheat) by altering phonological indexes through root growth (Neumann, 1995), root/shoot ratio (El-Hendawy, 2005), osmoticum components (Hamdia, 2004), ions imbalance (Wakeel, 2013) and total dry matter (Pessarakli and Huber, 1991).

Cadmium $(\mathrm{Cd})$ is a heavy metal, considered harmful to plants, animals and also human beings (Yamaguchi et al., 2009). It occurs naturally in the earth's crust and can be added to the environment via water and soil through natural weathering and human 
activities such as adding fertilizers, pesticides and industrial and/or domestic effluents (Alloway and Steinnes, 1999; Nriagu and Sprague, 1987; Sheppard et al., 2009). Its values range $0.2-1.0 \mathrm{mg} \mathrm{Kg}^{-1}$ of dry soil to $50 \mathrm{mg} \mathrm{Kg}^{-1}$ of agricultural soil. The maximum permissible addition (MPA) of the heavy metal/metalloid content in the soil is the key idea upon the standardization of the soil contamination (Vodyanitskii, 2016).

Although $\mathrm{Cd}$ is not essential for plant and biological systems, different crops will take up and accumulate $\mathrm{Cd}$ differently depending on its availability in the environment (Grant and Sheppard, 2008). However, Cd induces oxidative stress, which damages cellular organelles in many plants (Yadav and Chandra, 2013). In addition, Cd could interfere with the uptake of some mineral nutrition such as iron and calcium (Astolfi, 2012; Roth, 2006) and causes mineral concentration imbalance (Chang et al., 2012; Dražić et al, 2004; Lux et al., 2011).

Salinity and heavy metals impose adverse effects on plant growth and its productivity especially in arid and semi-arid regions (Leblebici et al., 2011). Several researchers have reported higher toxic effects of $\mathrm{Cd}$ in saline condition (Khoshgoftar et al., 2004). Although the addition of $\mathrm{NaCl}$ causes higher sodium absorption by a plant which decreases plant production (Dražić et al., 2004). Chloride of $\mathrm{NaCl}$ forms $\mathrm{CdCl}_{2}$ in the present of $\mathrm{Cd}$ and therefore leads to more $\mathrm{Cd}$ absorption due to the much higher solubility of $\mathrm{CdCl}_{2}$ among its $\mathrm{Cd}$ components. $\mathrm{CdCl}_{2}$ has solubility limit of $1,680,000$ $\mathrm{mg} \mathrm{L}^{-1}$ at $20^{\circ} \mathrm{C}$ in water (National Research Council, 1997). This condition causes more Cd toxicity for plant growth (Smolders et al., 1998).

Plant growth promotion rhizobacteria (PGPRs) help the plant to grow better by different mechanisms. It has been reported that PGPRs act in favor of plant mineral uptake (Askary et al., 2009), more phytohormones production (Kang et al., 2014) as well as modification in some gene expression (Vargas-Garcia et al., 2012). Creus et al. (1997) also confirmed the reduction of adverse effects of salinity and osmotic stresses on the length and dry weight of wheat plants when inoculated by Azospirillum brasilense.

Concerning inoculation and heavy metal, there are two consequences of using PGPRs in environments polluted by heavy metals. Some researchers believe that PGPRs can absorb and accumulate heavy metals and reduce soil and water pollution level (Belimov et al., 2005; Ma et al., 2009; Prapagdee and Khonsue, 2015), while some others believe PGPRs are able to reduce the availability of heavy metals in the soil and water which in turn lead to more growth and yield production (Belimov et al., 2005; Belimov and Dietz, 2000; Dell'Amico et al., 2008; Gao et al., 2012). In any way, one of the safe approaches to revert the detrimental effects of $\mathrm{Cd}$ and salinity on crop production is establishing an associated system between crops and soil microorganisms such as Azospirillum species with wheat cultivars. Azospirillum spp. not only can improve wheat productivity through higher root and shoot development (Amooaghaie et al., 2002), more nutrient uptake (Askary et al., 2009) and improvement of phytohormones but also can reduce adverse effects of salinity and $\mathrm{Cd}$ under saline (Upadhyay et al., 2011) and Cd-stressed conditions (Belimov and Dietz, 2000).

Kim et al. (2008) showed Triticum aestivum transmembrane 20 (TaTM20) gene expression in wheat plant upregulated due to the excess of $\mathrm{Cd}$. They also showed that this gene confers Cd tolerance to yeast transgenic containing TaTM20 gene. Ramezani et al. (2013) and Kim et al., (2008) The upregulation of salt overly sensitive 1 (TaSOS1) and TaTM20 under saline condition (Ramezani et al., 2013) and TaTM20 upregulation under Cd polluted conditions (Kim et al., 2008) are also reported. Xu et al. (2008) demonstrated SOS1 upregulation at both roots and shoots of wheat plants under saline condition. They 
also showed that yeast transgenic containing TaSOS1 gene has higher salt tolerance as compared to non-transgenic ones. In addition, Taherinia et al. (2015) revealed that salinization was affected SOS1 transcript level positively in kallar grass (Leptochloa fusca L.) a halophyte plant which is highly tolerant to saline and sodic soil and water.

Accordingly, it can be proposed that Azospirillum species may contribute to the upregulation of TaSOS1 and TaTM2O gene expression in wheat plants under saline and $\mathrm{Cd}$ polluted condition and improve salinity and $\mathrm{Cd}$ tolerance. Not only that, Azospirillum may help to limit $\mathrm{Cd}$ absorption by plant root. Therefore, this research was conducted to evaluate TaSOS1 and TaTM20 gene expression in the roots and also chlorophyll ( $a$ and $b$ ) and carotenoid of the shoots. Simultaneously other indexes such as $\mathrm{Fe}, \mathrm{Ca}, \mathrm{K}, \mathrm{Na}, \mathrm{Cd}$, proline, antioxidant enzymes (CAT and APX) of the roots and shoots of wheat seedlings (Sardari cultivar) were measured under excess of salinity, Cd and inoculated conditions.

\section{Materials and methods}

\section{Preparation of inoculants and seeds}

Azospirillum brasilense $\mathrm{Sp} 7$ (standard strain) was obtained from NCIMB Ltd, Germany. Then cultured in an $\mathrm{NFb}$ liquid medium supplemented with $\mathrm{NH}_{4} \mathrm{Cl}\left(0.25 \mathrm{~g} \mathrm{~L}^{-1}\right)$ at $30^{\circ} \mathrm{C}$ (Brenner et al., 2005) in Erlenmeyer flasks for $48 \mathrm{~h}$ and used a rotary shaker at $200 \mathrm{rpm}$ (logarithmic phase). The growth was harvested by centrifuging (1000 g, $10 \mathrm{~min}$ ), washed with sterile saline phosphate buffer and then re-suspended in phosphate buffer at concentration of $10^{7} \mathrm{CFU} \mathrm{ml}^{-1}$ of $A$. brasilense Sp7 (Askary et al., 2009).

Wheat (Triticum aestivum L., Sardari cv.) seeds obtained from Institute of Agricultural and Research, Isfahan, Iran. The seeds were surface sterilized by dipping in 95\% ethanol for $2 \mathrm{~min}$ and then in 1\% sodium hypochlorite $(\mathrm{NaOCl})$ for 1 min followed by six washes in sterile distilled water (Sauer and Burroughs, 1986). The sterilized wheat seeds were vernalized at $4^{\circ} \mathrm{C}$ for one night.

For germination, sterilized seeds were kept in dark on water agar in autoclaved petridishes held at $25{ }^{\circ} \mathrm{C}$ temperature. After 24 hours, uniform seedlings were divided into two groups. The first group was inoculated by $10^{7} \mathrm{CFU} \mathrm{ml}{ }^{-1}$ A. brasilense $\mathrm{Sp} 7$ and the second group transferred into free bacteria phosphate buffer (Bashan, 1990) as control (non-inoculated). After 3 hours, all plants (inoculated and none inoculated) were transferred into pots containing sterile perlite and irrigated with $1 / 4$ strength of Hoagland's nutrient solution (Hoagland and Arnon, 1950). The plants kept in a glasshouse under 16/8 h (Light/Dark) photoperiod using white light (photon density 650 $\mu \mathrm{mol} \mathrm{m} \mathrm{m}^{-2} \mathrm{~S}^{-1}$ ) at $25 \pm 2{ }^{\circ} \mathrm{C}$ for 5 days. Then, besides control pots, both groups were treated with $200 \mathrm{mM}$ of $\mathrm{NaCl}$ and/or $50 \mathrm{mg} \mathrm{L}^{-1}$ of cadmium as $\mathrm{CdCl}_{2}$ as treatment for five more days. This experiment conducted in a completely randomized design with three replicates. At day-10 of the experiment (five days after salt and $\mathrm{Cd}$ stresses applied), roots and shoots of plant samples were separated and washed with distilled water. Some of the separated plant samples immediately frozen in liquid nitrogen for real-time quantitative PCR and the remaining samples were used for different analysis.

\section{Real-time quantitative PCR}

Real-time PCR was performed using RB SYBR master mix (RNA Biotech, Iran). The total RNA was isolated from frozen roots using Iraizol reagent (RNA biotech, Iran) 
and the first strand cDNA was synthesized using the M-MLV reverse transcriptase (Fermatas). Gene-specific primers were used for TaSOS1 (Gen Bank Accession No. AY326952), TaTM20 (Gen Bank Accession No. DQ323065) and G3PDH (Gen Bank Accession No. EU022331). The sequences of the primers designed to amplify TaTM20 were as follows: 5'-CCGATCCTCTTGCACAACTA-3' and 5'ATGGACAGCATGAAGCTCAC-3'; (Kim et al., 2008) the primers for $G 3 P D H$ were as follows: 5-TCACCACCGAGTACATGACC-3' 5' TCGTCCTTGAGCTTGATGT-3' (Kim et al., 2008); and the primers for TaSOS1 were as follows: 5'-GGGATGATGAGGAACTTGGG-3' in sense direction and 5'CTTGTCAGGAACATCGTGGG-3' in anti-sense direction (Xu et al., 2008). The PCR conditions were $94{ }^{\circ} \mathrm{C}$ for 4 min followed by 40 cycles of $94{ }^{\circ} \mathrm{C}$ for $10 \mathrm{~s}, 62^{\circ} \mathrm{C}$ for $40 \mathrm{~s}$, $72{ }^{\circ} \mathrm{C}$ for $60 \mathrm{~s}$, followed by $7 \mathrm{~min}$ at $72{ }^{\circ} \mathrm{C}$. Serial dilutions of cDNA were used to obtain optimized standard curve amplification efficiency and the best cDNA concentration for real-time PCR. The relative expression of each gene as the fold expression was calculated through Livak and Schmittgen's method (2001).

\section{Plant pigment determination}

Chlorophyll $\mathrm{a}$ and $\mathrm{b}$ and carotenoid were performed according to Arnon (1967) with some modifications. $100 \mathrm{mg}$ fresh leaves were homogenized in $2 \mathrm{ml} 80 \%$ acetone with mortar. Homogenates were centrifuged at $4^{\circ} \mathrm{C}$ for $10 \mathrm{~min}(3500 \mathrm{rpm})$. Supernatants were used for the analysis of pigments. Absorbance of plant sample was determined at 645, 663 and $470 \mathrm{~nm}$, respectively and then the following equations (Eq. 1-3) were used for calculation of different pigments.

$$
\begin{gathered}
\text { Chlorophyll } a=\frac{\left(19.3 \times A_{66 \mathrm{~B}}-0.86 \times A_{645}\right) \mathrm{V}}{100 \mathrm{~W}}(\mathrm{Eq} .1) \\
\text { Chlorophyll } b=\frac{\left(19.3 \times A_{645}-3.6 \times A_{668}\right) \mathrm{V}}{100 \mathrm{~W}} \\
\text { Carotenoids }=\frac{100\left(\mathrm{~A}_{470}\right)-3.27(\mathrm{mgChla})-104(\mathrm{mg} \mathrm{Chl} \mathrm{b]})}{227}
\end{gathered}
$$

\section{Determination of sodium and potassium content}

Sodium and potassium content of shoot and root were measured based on the method described by Skoog et al. (2005). To do so, $100 \mathrm{mg}$ powder of dry sample $\left(70{ }^{\circ} \mathrm{C}\right.$ for 72 hours) was digested with $10 \mathrm{ml} 3 \%$ (w/v) aqueous sulfosalicylic acid for $24 \mathrm{~h}$ at $4{ }^{\circ} \mathrm{C}$, then sample extract was purified using Whatman No. 1 filter paper. $\mathrm{Na}^{+}$and $\mathrm{K}^{+}$ concentration were measured using flame photometry method (Gallenkamp flame analyzer, England).

\section{Determination of $\mathrm{Ca}, \mathrm{Cd}$, and $\mathrm{Fe}$}

$100 \mathrm{mg}$ dry weight of each sample (roots and shoots separately) was digested in 3 $\mathrm{ml}$ of a $1-4(\mathrm{v} / \mathrm{v})$ mixture of $37 \%(\mathrm{v} / \mathrm{v}) \mathrm{HCl}$ and $65 \%(\mathrm{v} / \mathrm{v}) \mathrm{HNO}_{3}$ in Teflon cylinders for $7 \mathrm{~h}$ at $140{ }^{\circ} \mathrm{C}$. After adjustment of volume to $10 \mathrm{ml}$ with deionized water, $\mathrm{Ca}, \mathrm{Cd}$, and $\mathrm{Fe}$ was determined using an atomic absorption spectrophotometer (AAS, Shimadzu model 6200). 


\section{Determination of proline content}

Proline content of roots and shoots were determined using Bates et al. (1973) method. The fresh plant samples $(100 \mathrm{mg}$ ) was homogenized with $4 \mathrm{~mL}$ sulfosalicylic acid $(3.0 \%)$ in a mortar. The suspension was centrifuged at room temperature at 3000 rpm for $5 \mathrm{~min}$. The supernatant was mixed well with $4 \mathrm{~mL}$ acidic ninhydrin reagent. The reaction mixture was vortexed and the content of the tubes was placed in a boiling water bath for $60 \mathrm{~min}$. Then, the content was cooled in the ice bath and the mixture was extracted with $4 \mathrm{~mL}$ of toluene. The absorbance of toluene layer was recorded at 520 nm using Shimadzu spectrophotometer (Shimadzu UV-160, Japan). The concentration of the unknown samples was calculated using standard curve.

\section{Enzyme extract and antioxidant assay}

Plant's shoot samples were extracted for enzymes assay by homogenizing in an icecold 50-mM sodium phosphate buffer of $\mathrm{pH} 7.4$ along with $1 \%(\mathrm{w} / \mathrm{v})$ polyvinyl poly pyrrolidone (PVP) by a pre-chilled mortar and pestle. Homogenized mixture was centrifuged at $13000 \mathrm{~g}$ for $20 \mathrm{~min}$ at $4^{\circ} \mathrm{C}$. The supernatant was directly used for various enzymatic assay as crude enzyme extract. The quantification of soluble protein present in the extract was done by Bradford's method (Bradford, 1976) using bovine serum albumin (BSA) as standard. Catalase (CAT) activity (EC.1.11.1.6) was measured by estimating the breakdown of $\mathrm{H}_{2} \mathrm{O}_{2}$, which was determined at $240 \mathrm{~nm}$ as described by Beers and Sizer (1952). The enzyme activity was expressed as $\mu$ mol decomposition of $\mathrm{H}_{2} \mathrm{O}_{2} \mathrm{~min}^{-1} \mathrm{mg}^{-1}$ protein. Ascorbate peroxidase (EC.1.11.1.11) activity was done by using the method described by Nakano and Asada (1981) and the enzyme activity was expressed as $\mu \mathrm{mol}$ decomposition of ascorbate $\mathrm{min}^{-1} \mathrm{mg}^{-1}$ protein.

\section{Statistical analysis}

MSTAT-C software was used for ANOVA calculation and Duncan's multiple range tests were used to compare the mean values using $95 \%$ confidence interval. Excel was used to draw the necessary graphs. The experiment was a completely randomized design.

\section{Results}

\section{Root and shoot dry weight}

The maximum amount of root $\left(7.44 \mathrm{mg} \mathrm{plant}^{-1}\right)$ and shoot $\left(21.91 \mathrm{mg}\right.$ plant $\left.^{-1}\right)$ dry weight was observed in inoculated plants not exposed to any salinity and/or Cd. At noninoculated condition, adding $\mathrm{Cd}$ to the nutrient media has caused a significant reduction in dry weight of root (24.1) and shoot $(18.1 \%)$ as compared to their control $(\mathrm{P} \leq 0.05)$, while dry weight of shoot and root wheat seedlings unaffected under $200 \mathrm{mmol} \mathrm{NaCl}$ (Fig. 1). The dual stresses of salinity and Cd lead to more reduction of roots $(14.8 \%)$ and shoots $(9.0 \%)$ dry weight when compared with the Cd stress alone.

In inoculated plants not exposed to $\mathrm{Cd}$ and/or salinity, root and shoot dry weight significantly were increased by 22.97 and $9.7 \%$, respectively in comparison to their control. At $\mathrm{Cd}$ stress condition, inoculation significantly alleviated harmful effects of $\mathrm{Cd}$ on shoot dry weight as compared to non-inoculated plants. Root and shoot dry weight of inoculated seedlings and also the seedling plants were grown under saline condition showed significant difference when compared with control seedlings. 
Although in dual stresses a reduction in root and shoot dry weight of inoculated plants were observed, but inoculation significantly improved the root and shoot dry weight by 12.8 and $16.67 \%$, respectively when compared to non-inoculated ones.

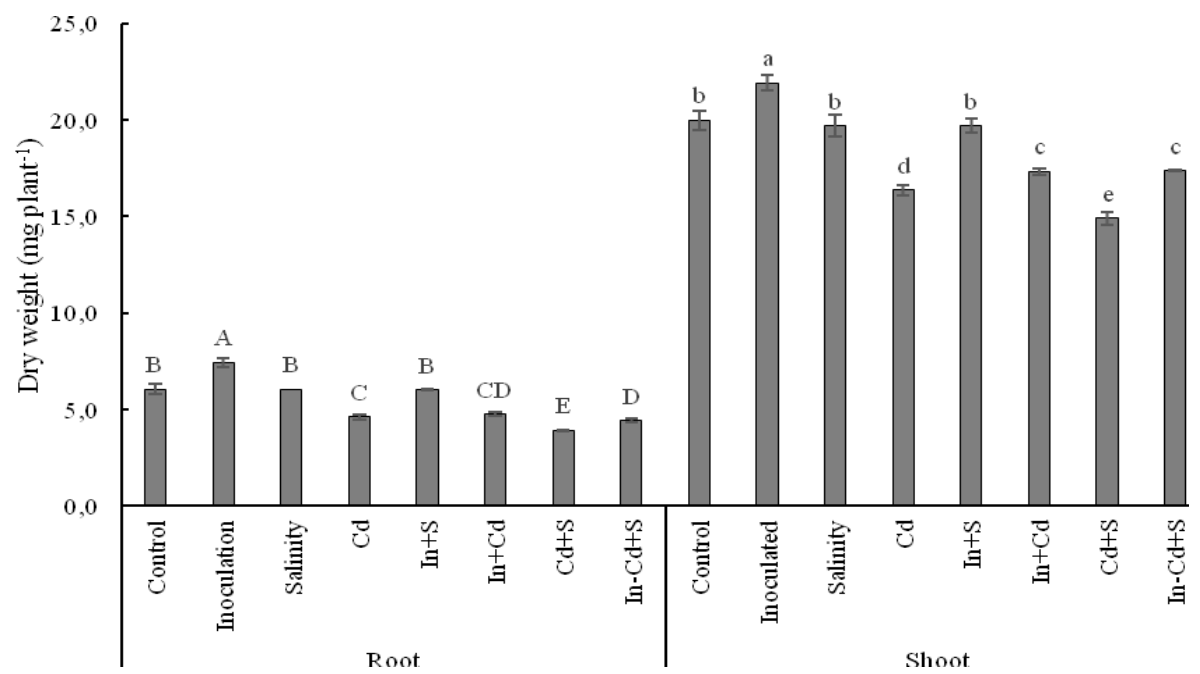

Figure 1. Effect of inoculation, salinity and $C d$ on average $(n=3 \pm S D)$ dry weight of roots and shoots of wheat seedlings. Differences in lower and upper case letters on the bar graph indicated significant difference $(P<0.05)$ in their mean values based on Duncan's multiple range tests.

\section{Root and shoot proline content}

Inoculated seedlings had lower proline in the root and the shoot when compared to control plants. Salinity didn't have a significant effect on shoot proline, meanwhile, proline of root was increased from 0.7 to $1.14 \mu \mathrm{mol} \mathrm{g}^{-1} \mathrm{FW}(\mathrm{P}<0.05$, Fig. 2). Cd also showed a significantly $(\mathrm{P}<0.05)$ increase in proline of root and shoot by 60 and $44 \%$, respectively. Dual effect of $\mathrm{Cd}$ and salinity causes an addition of proline in the root $(21.4 \%)$ and shoot (13.0\%) of non-inoculated plants compared to control seedlings.

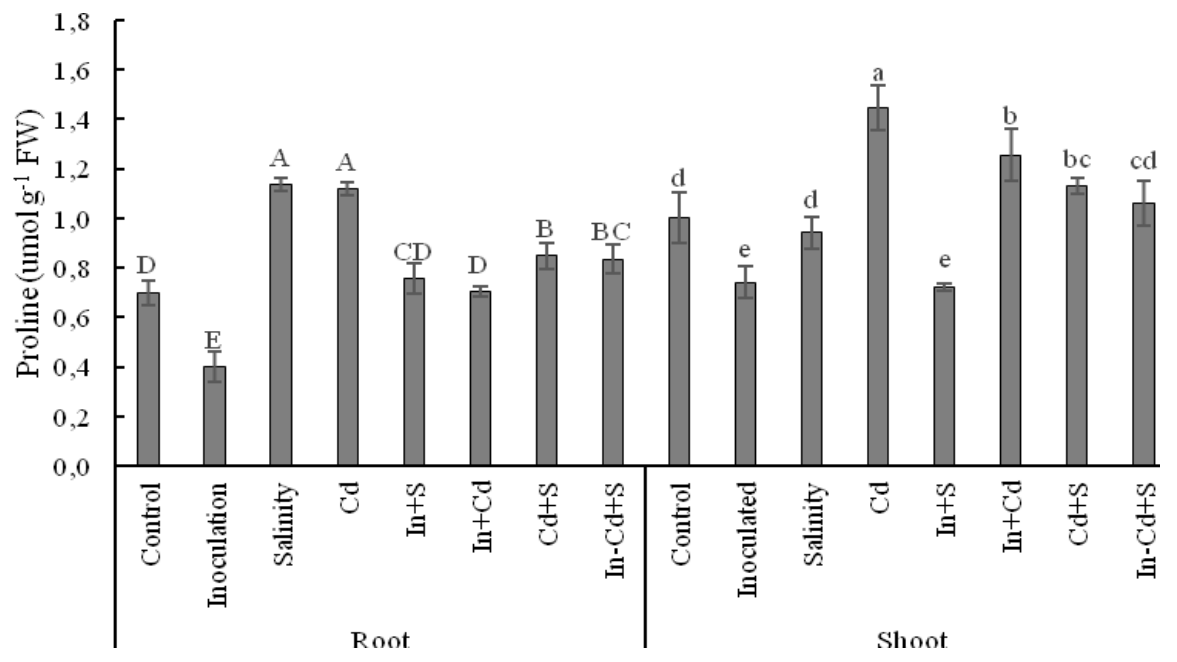

Figure 2. Effect of inoculation, salinity and Cd on average $(n=3 \pm S D)$ proline content of roots and shoots of wheat seedlings $(n=3 \pm S D)$. Differences in small and cap letters on the bar graph indicated difference in their mean values based on Duncan's multiple range tests. 
The lowest amount of proline was measured in the root and the shoot of inoculated plants not exposed to $\mathrm{Cd}$ and/or salinity. However, the higher values of proline in the root was measured under excess of salinity and $\mathrm{Cd}$ and in the shoot belonged to $\mathrm{Cd}$ treatment. When seedlings were inoculated with Azospirillum brasilense then the high proline accumulation under $\mathrm{Cd}$ excess and/or salinity significantly has been reduced to lower amounts which were still higher than in control plants.

\section{Shoot pigments}

Inoculation caused addition (22\%) of chlorophyll a when compared to control seedlings. In comparison to control plants, significantly less chlorophyll $(\mathrm{P}<0.05$, Table 1) was seen in the shoot of seedlings exposed to $\mathrm{Cd}$ or Cd+salinity (56.10 and $51.22 \%$, respectively). However, inoculation was increased chlorophyll a of seedlings exposed to $\mathrm{Cd}$ or $\mathrm{Cd}+$ slinity as much as control plants. The amount of chlorophyll $\mathrm{b}$ was reduced more under $\mathrm{Cd}$ than salinity in non-inoculated plants. In contrast, chlorophyll $\mathrm{b}$ was increased in inoculated plants under salinity and/or $\mathrm{Cd}$, but it was still lower than control plants. Total chlorophyll ( $a$ and $b$ ) showed a positive relation with inoculation while a negative relation was observed in excess of $\mathrm{Cd}$ and/or salinity conditions with total chlorophyll. $\mathrm{Cd}(55.36 \%)$ and $\mathrm{Cd}+$ salinity $(53.56 \%)$ significantly decreased total chlorophyll of non-inoculated seedlings as compared to control plants.

Maximum total chlorophyll (0.65 mg Plant $\left.{ }^{-1}\right)$ was observed in inoculated not exposed to any treatment. The maximum reduction of total chlorophyll was seen under excess $\mathrm{Cd}$ and $\mathrm{Cd}+$ salinity in non-inoculated seedlings when compared to control plants.

Table 1. Effect of inoculation, salinity and Cd on the mean values $(n=3)$ of chlorophylls $(a$, $b$, total) and Carotenoids in the shoot of wheat seedlings. Differences in the letters on the mean values indicated the significant difference in their means based on Duncan's multiple range tests.

\begin{tabular}{lcccc}
\hline Treatments & Chlorophyll a & Chlorophyll b & Total chlorophyll & Carotenoids \\
\hline Control & $0.41^{\mathrm{B}}$ & $0.15^{\mathrm{A}}$ & $0.56^{\mathrm{B}}$ & $1.35^{\mathrm{D}}$ \\
Inoculation (In) & $0.50^{\mathrm{A}}$ & $0.16^{\mathrm{A}}$ & $0.65^{\mathrm{A}}$ & $1.36^{\mathrm{CD}}$ \\
Salinity (Sal) & $0.40^{\mathrm{B}}$ & $0.12^{\mathrm{C}}$ & $0.52^{\mathrm{B}}$ & $1.56^{\mathrm{B}}$ \\
Cadmium (Cd) & $0.18^{\mathrm{C}}$ & $0.06^{\mathrm{D}}$ & $0.25^{\mathrm{C}}$ & $0.70^{\mathrm{E}}$ \\
In + S & $0.43^{\mathrm{B}}$ & $0.13^{\mathrm{B}}$ & $0.56^{\mathrm{B}}$ & $1.70^{\mathrm{A}}$ \\
In + Cd & $0.41^{\mathrm{B}}$ & $0.14^{\mathrm{B}}$ & $0.54^{\mathrm{B}}$ & $1.48^{\mathrm{BC}}$ \\
Cd + Sal & $0.20^{\mathrm{C}}$ & $0.06^{\mathrm{D}}$ & $0.26^{\mathrm{C}}$ & $0.72^{\mathrm{E}}$ \\
In + Sal + Cd & $0.40^{\mathrm{B}}$ & $0.14^{\mathrm{B}}$ & $0.54^{\mathrm{B}}$ & $1.40^{\mathrm{CD}}$ \\
\hline
\end{tabular}

\section{Antioxidant assays}

In most cases, the amount of APX and CAT activities were higher in the shoot than root seedlings and also the amount of CAT activity was higher than APX. The lowest and the highest activities of APX were observed in root and shoot of control and treated seedlings expose to $\mathrm{Cd}+$ salinity. Their amounts in the roots were 0.41 and $1.22 \mu \mathrm{mol}$ $\min ^{-1} \mathrm{mg}^{-1}$ protein $\left(\mathrm{P}<0.05\right.$, Fig. 3) and for shoot were 0.29 and $1.42 \mu \mathrm{mol} \mathrm{min} \mathrm{mg}^{-1}$ protein, respectively. This is almost $197.5 \%$ addition in roots and $389.6 \%$ for shoots. Inoculation did not have any effect on APX activity of seedlings compared to control. 
However, inoculation caused reduction of APX activities of the seedlings exposed to Cd and/or salinity but their amounts still were more than control seedlings.

Change in CAT activities under different conditions was approximately similar to APX activities of the roots and shoots. The lowest and the highest activities of CAT were observed in root and shoot of control and treated seedlings expose to $\mathrm{Cd}+$ salinity. Their amounts in the roots were 0.5 and $1.35 \mu \mathrm{mol} \mathrm{min} \mathrm{mg}^{-1}$ protein $(\mathrm{P}<0.05$, Fig. 3) and for shoot were 0.25 and $1.17 \mu \mathrm{mol} \mathrm{min} \mathrm{mg}^{-1}$ protein, respectively. This is almost $170.0 \%$ addition in roots and $368 \%$ for shoots. Inoculation did not have any effect on CAT activity of seedlings compared to control. However, inoculation also showed no changes in CAT activities of the seedlings exposed to Cd or salinity but their amounts still were more than control seedlings.
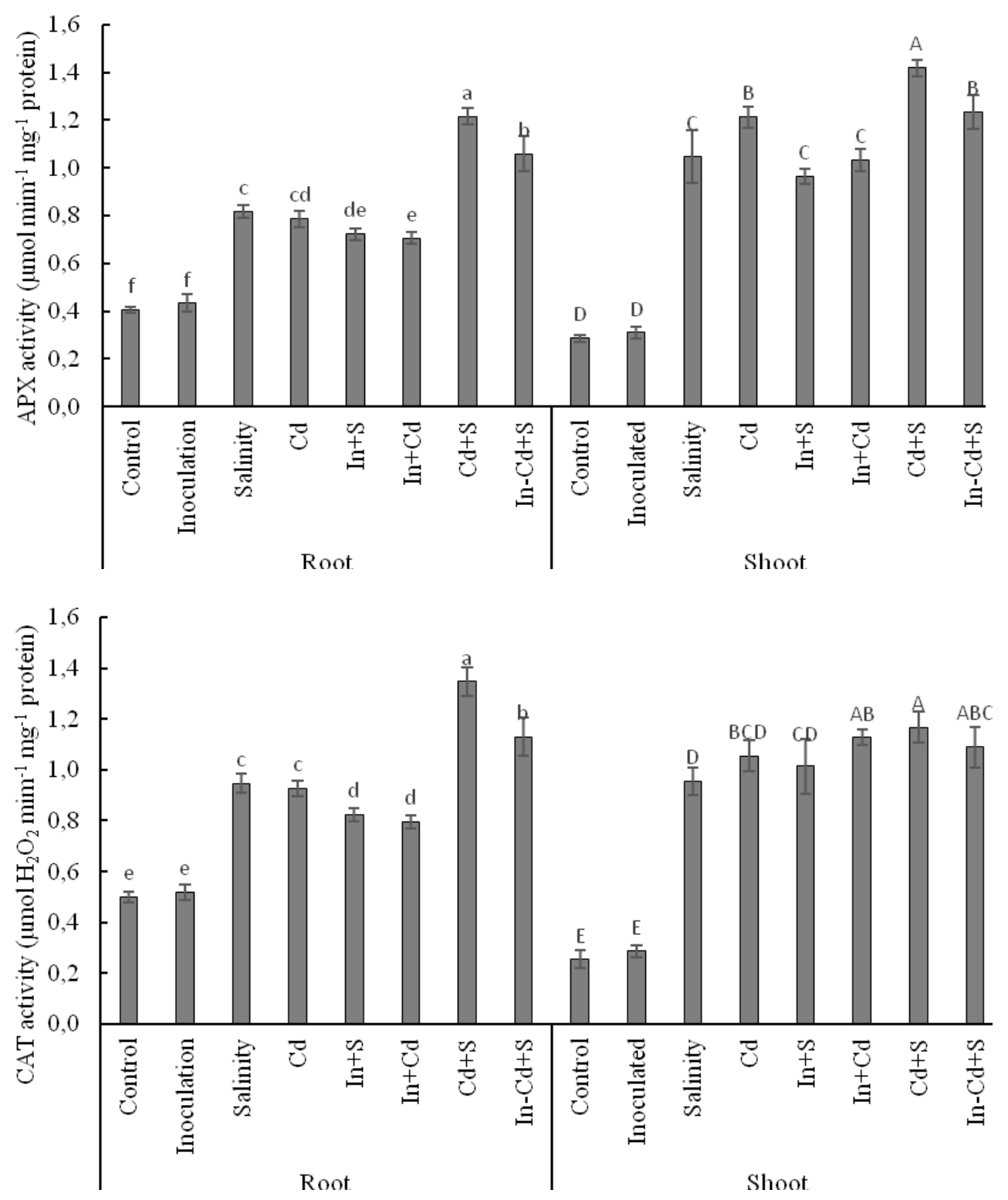

Figure 3. Effect of Salinity (Sal) and Cd, inoculation (In) and their interactions on the activities of APX and CAT in the shoot of wheat seedlings in inoculated and non-inoculated condition. Mean values $(n=3)$ with the same letter are not significantly different at $P<0.05$. 


\section{Cadmium, sodium, potassium, calcium and iron of root and shoot}

There was not any $\mathrm{Cd}$ in the root of seedlings of non-inoculated or inoculated plants under control and salinity conditions. While its amount in the root of treated seedlings was increased to $32.18 \mathrm{mg} \mathrm{g}^{-1}$ (Cd-treated), 28.27 (Cd and inoculated), 38.49 (Cd and salinity) and $33.29 \mathrm{mg} \mathrm{g}^{-1} \mathrm{DW}$ for inoculated+Cd+salinity treated seedlings. It was found that the amount of $\mathrm{Cd}$ in $\mathrm{Cd}+$ salinity treated of non-inoculated plants was the highest and significantly $(\mathrm{P}<0.05)$ higher than the other treatments. Also, inoculation reduced the $\mathrm{Cd}$ concentration of plant exposed to $\mathrm{Cd}$. It is interesting that $\mathrm{Cd}$ in the shoot of inoculated seedlings $\left(7.52 \mathrm{mg} \mathrm{g}^{-1} \mathrm{DW}\right)$ did not show significant reduction compared to non-inoculated plants exposed to $\mathrm{Cd}\left(7.01 \mathrm{mg} \mathrm{g}^{-1} \mathrm{DW}\right)$. At non-inoculation condition, the $\mathrm{Cd}$ of roots and shoots raised due to the combined effect of $\mathrm{Cd}+$ salinity.

In non-inoculated seedlings, the amount of Fe in the roots and shoots (Table 2) was the highest $\left(0.38\right.$ and $0.16 \mathrm{mg} \mathrm{g}^{-1} \mathrm{DW}$, respectively) and a significant reduction was observed in roots treated with $\mathrm{Cd}(21.05)$ and salinity (23.68\%) stress, but inoculation couldn't help the Fe uptake by the roots under $\mathrm{Cd}$ and/or salinity conditions. However, Azospirillum helped to increase the amount of $\mathrm{Fe}$ in unstresses seedlings to more than control plants and reached to $0.51 \mathrm{mg} \mathrm{g}^{-1} \mathrm{DW}$ (the highest amount). Fe in the shoots and roots of inoculated and non-inoculated seedlings followed a similar trend.

Table 2. Effect of various tested treatments on roots and shoots nutrients of seedlings wheat plants. Values with the same letter are not significantly different at $P<0.05$.

\begin{tabular}{|c|c|c|c|c|c|c|c|c|c|c|}
\hline \multirow[b]{2}{*}{ Treatments } & \multicolumn{5}{|c|}{ Root $\left(\mathrm{mg} \mathrm{g}^{-1} \mathrm{DW}\right)$} & \multicolumn{5}{|c|}{ Shoot $\left(\mathrm{mg} \mathrm{g}^{-1} \mathrm{DW}\right)$} \\
\hline & Cd & $\mathbf{F e}$ & $\mathbf{C a}$ & $\mathbf{N a}$ & $\mathbf{K}$ & Cd & $\mathbf{F e}$ & $\mathbf{C a}$ & $\mathbf{N a}$ & $\mathbf{K}$ \\
\hline Non-inoculated & $0.00^{\mathrm{D}}$ & $0.38^{\mathrm{B}}$ & $1.88^{\mathrm{B}}$ & $1.32^{\mathrm{E}}$ & $6.30^{\mathrm{B}}$ & $0.00^{\mathrm{C}}$ & $0.16^{\mathrm{B}}$ & $2.22^{\mathrm{B}}$ & $0.49^{\mathrm{B}}$ & $18.28^{\mathrm{B}}$ \\
\hline Inoculated (In) & $0.00^{\mathrm{D}}$ & $0.51^{\mathrm{A}}$ & $2.14^{\mathrm{A}}$ & $0.80^{\mathrm{F}}$ & $9.87^{\mathrm{A}}$ & $0.00^{\mathrm{C}}$ & $0.22^{\mathrm{A}}$ & $2.46^{\mathrm{A}}$ & $0.20^{\mathrm{E}}$ & $22.50^{\mathrm{A}}$ \\
\hline Salinity (Sal) & $0.00^{\mathrm{D}}$ & $0.29^{\mathrm{D}}$ & $1.15^{\mathrm{D}}$ & $1.83^{\mathrm{A}}$ & $4.81^{\mathrm{D}}$ & $0.00^{\mathrm{C}}$ & $0.11^{\mathrm{C}}$ & $1.53^{\mathrm{D}}$ & $0.60^{\mathrm{A}}$ & $15.70^{\mathrm{DE}}$ \\
\hline Cadmium $(\mathrm{Cd})$ & $32.18^{\mathrm{B}}$ & $0.30^{\mathrm{CD}}$ & $1.07^{\mathrm{D}}$ & $1.76^{\mathrm{AB}}$ & $4.83^{\mathrm{D}}$ & $7.01^{\mathrm{B}}$ & $0.12^{\mathrm{C}}$ & $1.57^{\mathrm{D}}$ & $0.58^{\mathrm{A}}$ & $15.50^{\mathrm{DE}}$ \\
\hline $\mathrm{In}+\mathrm{Sal}$ & $0.00^{\mathrm{D}}$ & $0.32^{\mathrm{C}}$ & $1.52^{\mathrm{C}}$ & $1.59^{\mathrm{D}}$ & $5.35^{\mathrm{C}}$ & $0.00^{\mathrm{C}}$ & $0.13^{\mathrm{C}}$ & $2.04^{\mathrm{BC}}$ & $0.30^{\mathrm{D}}$ & $17.08^{\mathrm{BC}}$ \\
\hline $\mathrm{In}+\mathrm{Cd}$ & $28.27^{\mathrm{C}}$ & $0.31^{\mathrm{CD}}$ & $1.55^{\mathrm{C}}$ & $1.62^{\mathrm{CD}}$ & $5.34^{\mathrm{C}}$ & $7.52^{\mathrm{AB}}$ & $0.13^{\mathrm{C}}$ & $1.95^{\mathrm{C}}$ & $0.33^{\mathrm{CD}}$ & $16.67^{\mathrm{CD}}$ \\
\hline $\mathrm{Cd}+\mathrm{Sal}$ & $38.49^{\mathrm{A}}$ & $0.30^{\mathrm{CD}}$ & $1.13^{\mathrm{D}}$ & $1.71^{\mathrm{BC}}$ & $4.72^{\mathrm{D}}$ & $7.66^{\mathrm{A}}$ & $0.11^{\mathrm{C}}$ & $1.60^{\mathrm{D}}$ & $0.56^{\mathrm{A}}$ & $15.30^{\mathrm{E}}$ \\
\hline $\mathrm{In}+\mathrm{Sal}+\mathrm{Cd}$ & $33.22^{\mathrm{B}}$ & $0.31^{\mathrm{CD}}$ & $1.56^{\mathrm{C}}$ & $1.55^{\mathrm{D}}$ & $5.26^{\mathrm{C}}$ & $7.71^{\mathrm{A}}$ & $0.12^{\mathrm{C}}$ & $1.92^{\mathrm{C}}$ & $0.37^{\mathrm{C}}$ & $16.18^{\mathrm{CDE}}$ \\
\hline
\end{tabular}

Calcium concentration in the roots and shoots of inoculated plants not exposed to salinity and/or $\mathrm{Cd}$ increased by 13.83 and $10.81 \%$, respectively when compared to control plants. $\mathrm{Cd}$, or salinity and also salinity+Cd in both roots and shoots of seedlings caused a significant reduction in $\mathrm{Ca}$ content. However, inoculation was improved its amount in the root and shoot but their amount was still less than the control ones.

In non-inoculated condition, the amount of $\mathrm{Na}$ in the root and shoot was 1.32 and 0.49 $\mathrm{mg} \mathrm{g}^{-1} \mathrm{DW}$. While application of salinity increased $\mathrm{Na}$ of the roots $(38.63 \%)$ and shoots $(22.45 \%)$ in non-inoculated plants. Dual effect of $\mathrm{Cd}$ and salinity show the highest amount of $\mathrm{Na}$ in the roots and shoots; however, its amount was less in inoculated plants exposed to $\mathrm{Cd}$ and/or salinity. When plants were inoculated then the amount of $\mathrm{Na}$ in the roots and shoots decreased by $39.4 \%$ and $59.2 \%$, respectively. Simultaneously K of the roots and shoots increased by 56.6 and $23 \%$, respectively. Inoculation decreased harmful effects of $\mathrm{Cd}$ and/or salinity via less $\mathrm{Na}$ and increase in $\mathrm{K}$ uptake and its accumulation in the roots and shoots of inoculated plants. In whole plant (root and shoot), the best and the 
worst conditions for $\mathrm{Na}$ content were measured in inoculated $\left(0.28 \mathrm{mg} \mathrm{g}^{-1} \mathrm{DW}\right)$ and salinity (2.43 $\mathrm{mg} \mathrm{g}^{-1} \mathrm{DW}$ ) seedlings, respectively. However, the worst and the best conditions for $K$ were seen in seedlings treated with $C d+$ salinity $\left(20.1 \mathrm{mg} \mathrm{g}^{-1} \mathrm{DW}\right)$ and inoculated but not exposed to any treatment $\left(32.3 \mathrm{mg} \mathrm{g}^{-1} \mathrm{DW}\right)$, respectively.

\section{TaSOS1 and TaTM20 genes expression}

In non-inoculated condition, there was not any significant expression and difference for TaSOS1 of roots in control and inoculated seedlings (Fig. 4) while Cd (14.13 fold change) and salinity (32.43 fold change) significantly caused addition of expression of TaSOS1. In inoculated seedlings, the TaSOS1 experession significantly was decreased in Cd-treated seedlings as equal as control seedlings, but there was higher expression of TaSOS1 under saline condition (61.03). In dual effects of Cd and salinity, the TaSOS1 expression was the highest (72.89 fold changes) and inoculation cause addition of its upreggulation under salinity but no effect under other treatments.
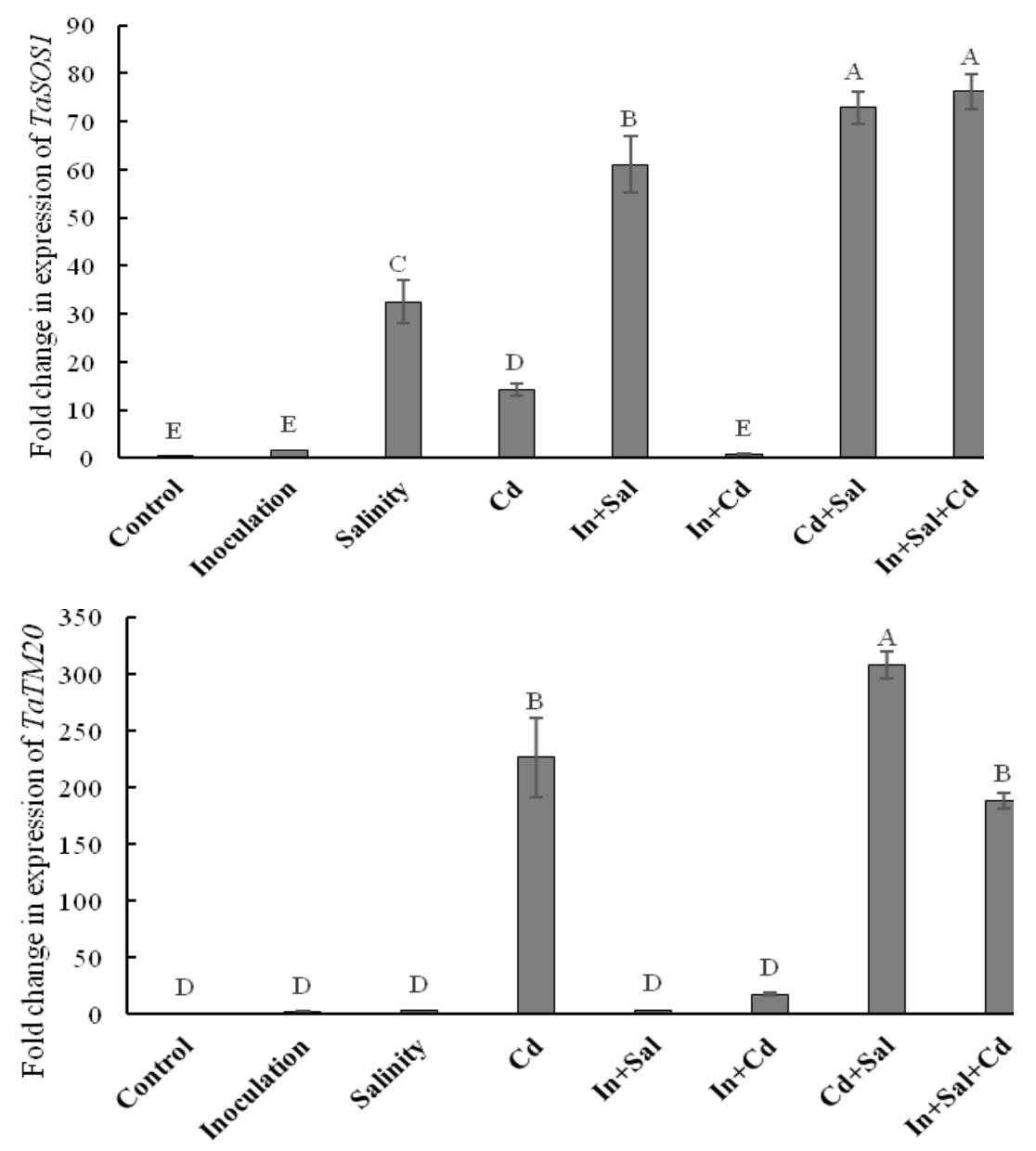

Figure 4. Fold change expression of TaSOS1 and TaTM2O genes in the root of inoculated (A. brasilense, $10^{7} \mathrm{CFU} \mathrm{ml}^{-1}$ ) and non-inoculated wheat seedlings grown under saline and nonsaline (200 mmol $\mathrm{NaCl}$ ) condition. The plant samples were obtained five days after salt application. The growth conditions were light density of $650 \mu \mathrm{mol} \mathrm{m} \mathrm{m}^{-2} \mathrm{~S}^{-1}$ and temperature of 25

${ }^{\circ} \mathrm{C}$. Each value represents mean of three individual measurements $\pm S E$. Different letters represent significant differences at the $95 \%$ confidence interval. 
There were no significant differences in TaTM20 gene expression in non-inoculated and inoculated seedlings when seedlins were not exposed to $\mathrm{Cd}$ or salinity. Simultaneously, salinity had no significant effect on TaTM20 expression either in inoculated or non-inoculated seedlings not exposed to $\mathrm{Cd}$. However, $\mathrm{Cd}$ by itself could increase TaTM20 expression significantly (226.3 fold change) in non-inoculaed seedlings but when inoculated with $A$. brasilense there was significantly less TaTM20 expression when compared to control seedlings. The highest effect in TaTM2O expression was seen in combined treatments of $\mathrm{Cd}$ and salinity (308.3 fold change). While this effect was lower (188.3 fold change) in dual effects under inoculated with A. brasilense.

\section{Discussion}

A large portion of agricultural land suffers from salinity, which causes a reduction in agricultural production (Siadat, 1998). Simultaneously, the deficiency of plant nutrients causes fertilizer application to increase crop yields (Adams, 1991; Dobermann, 2000). Most chemical fertilizers especially phosphorous and also manure mainly contains unwanted elements such as $\mathrm{Cd}$ and nickel (He and Singh, 1994). This is because of the waste application and industrial activities. Many researchers have pointed out that crops are affected by the excess of salinity and heavy metals (Corwin and Ahmad, 2015; Leblebici et al., 2011; Shah et al., 2011). Cd and $\mathrm{NaCl}$ have been identified as important abiotic stresses in crop production (Corwin and Ahmad, 2015; Mahajan and Tuteja, 2005).

Our results indicated that root and shoot dry weight decreased under excess of $\mathrm{Cd}$ and salinity $+\mathrm{Cd}$. This result is similar to that of Leblebici et al., (2011) who showed the relative growth rate of Lemnaceae plants (Spirodela polyrrhiza) was decreased under salinity+Cd condition. Excess $\mathrm{Cd}$ in the soil can reduce the growth of plants by direct or indirect effect on photosynthesis pigments, gas exchange parameters as well as plant nutrient imbalance (Gohar et al., 2003; Parida et al., 2003; Shah et al., 2011). Moreover, it is possible that shoot and root dry weight affected by the toxic effects of $\mathrm{Cd}$ due to mainly the chlorocomplexes formation (Weggler-Beaton et al., 2000). In contrast, plant growth promotion rhizobacteria (PGPRs) can reduce the harmful effects of salinity and Cd stress (El-Dengawy et al., 2011; Stout et al., 2010). Our results show Azosirilium brasilense improved salinity and/or Cd adverse effects on root and shoot dry weight. These results are accordance with the result obtained by Giller et al., (1998) who showed that bacteria can reduce the phytotoxicity of the contaminated soil by heavy metals. In addition, Stout et al., (2010) indicated that bacteria could serve as a phytoprotective factor in their relationship with Lemna minor, preventing uptake of toxic Cd. Also, El-Dengawy et al., (2011) reported that inoculation of Carob seedlings (Ceratonia siliqua L.) with A. lipoferum under saline condition could improve the reduction of seedling growth rate, $\mathrm{K}^{+} / \mathrm{Na}^{+}$content and root characters. PGPRs can help the plant to grow better by different mechanisms such as efficient mineral uptake (Askary et al., 2009), more phytohormones production (Kang et al., 2014) and better tolerant to abiotic stresses (Vargas-Garcia et al., 2012).

Salinity could lead to osmotic stress (Carillo et al., 2008), disruption of homeostasis and ion distribution (Zhang, 2008) as well as formation of reactive oxygen species (Matysik, 2002) in plant cell that has harmful effects on plant growth and its productivity. Proline production is one of the mechanisms that enable the plant to tolerate adverse effect of environmental stresses. Proline is thought to contribute to 
osmotic adjustment, detoxification of ROS, and protection of membrane integrity (Heuer, 2010). Addition of proline in our experiment is similar to Tavakoli et al., (2016) who showed saline condition could accumulate the proline content of three Iranian wheat cultivars. In addition, Sharmila et al., (2017) also demonstrated that Cd-induced iron deficiency and promotes proline accumulation in Brassica juncea plants. Although there are numerous reports related to accumulation of proline in plant cells after inoculation with some Azospirillum Spp.. Our result showed a negative correlation between proline content of non-inoculated wheat seedlings and inoculation ones with $A$. brasilense Sp7. This result may be due to the fact that Azospirillum Spp. may facilitate its beneficial effects in different ways on the host plant.

Many studies have shown a reduction in photosynthetic pigments in saline soil (Leblebici et al., 2011; Shafi et al., 2009; Tiwari, 2010 ; Jamil et al., 2007). Our result also showed a reduction in photosynthesis pigments of shoots under saline condition which is similar to the result of El-Dengawy et al., (2011) who demonstrated chlorophyll content decreased in response to salinity in leaves of carob seedlings. It seems that reduction in chlorophyll could be due to less number of chloroplast and disorganization of thylakoid's membrane structure in leaves under salt stress. In addition, our results are consistent with Cheng et al., (2013) who showed an increase in carotenoids of shoot as a way to cope with the saline condition, especially in glycophyte plants. Photosynthetic pigments may be negatively affected by $\mathrm{Cd}$ stress in different ways. For example, $\mathrm{Cd}$ prevented the chlorophyll production by affecting the synthesis of 5-aminolaevulinic acid, disabling the protochlorophyllide reductase (Stobart et al., 1985) and Fe deficiency (Fodor et al., 2005; Wallace et al., 1992). In addition, the increase in $\mathrm{Cd}$ concentration caused loss of chlorophyll and damage to membrane in two maize cultivars (Ekmekçi, et al., 2008). The result of this experiment showed a reduction of shoot chlorophyll due to excess of salinity and/or $\mathrm{Cd}$, meanwhile, $A$. brasilense was able to prevent further reduction of shoot chlorophyll under dual treatments (Table 1). This result in some way is similar to Zhang et al., (2008b) who indicated B. subtilis GB03 increases photosynthetic efficiency by increasing chlorophyll content in Arabidopsis. In addition, Wani and Khan (2010) showed that photosynthetic pigments of chickpea (Cicer arietinum L.) improved by Bacillus species under different $\mathrm{Cd}$ concentration. Reduction of chlorophyll in our experiment under $\mathrm{Cd}$ or salinity conditions should be one of the reasons for dry weight reduction and the higher reduction of dry weight in $\mathrm{Cd}+$ salinity could be due to more solubility of $\mathrm{Cd}$ under higher $\mathrm{NaCl}$ of the media.

Antioxidant enzymes activity have been studied specially under stress conditions (Asada, 2006; Shafi et al., 2009). It has been reported that antioxidant enzymes activity could be increase due to stressful condition. Our result clearly demonstrated that salt and/or Cd significantly have increased APX and CAT activity, but their amounts were decreased when seedlings were inoculated with A. brasilense under stress condition. Similar results are reported by different researches. Shafi et al., (2009) showed salinity and $\mathrm{Cd}$ stress caused an increase in enzymatic antioxidants such as CAT in three wheat cultivars. In addition, Asada (2006) indicated that APX plays an important role in plant defense against oxidative stress by scavenging $\mathrm{H}_{2} \mathrm{O}_{2}$. Salinity and $\mathrm{Cd}$ generate oxidative stress in plants, leading to a limited growth and even plant death. Oxidative stress is one of the main causes of cellular damage in all organisms exposed to a wide variety of stress conditions (Lin and Kao, 2001; Liu, 2006). It is well known that some of PGPRs such as Azospirillum Spp. could help and improve the adverse effect of oxidative stress. 
For instance, Bashan et al., (2005) showed inoculation of wheat plants with Azospirillum could increase auxiliary photoprotective pigments in shoot of plant which may protect chlorophyll from oxidation during exposure to salt stress. Furthermore, Othman (2015) showed the ability of A. brasilense Sp7 in production of ACC deaminase which may be responsible for better growth of rice seedlings. Under stress condition, excess ROS production leads to an increase in plant hormone such as ethylene to prevent the ROS induced damage to reduce the enzymatic antioxidants production (Cho and Seo, 2005). Afterward, degradation of the ethylene precursor ACC by bacterial ACC deaminase releases plant from ethylene induced stress (Figueiredo et al., 2008). In this experiment, inoculation could have alleviated the negative effects of salinity and/or Cd stress (Fig. 3). It appears that reduction in the activity of antioxidant enzymes may be due to the reduction of severity of stress experienced by inoculated seedlings. Omar et al., (2009) and Othman (2015) indicated that antioxidant enzyme activity significantly decreased in barely plants inoculated with $A$. brasilense.

Uptake of mineral by plant's root and its distribution was affected by a variety of factors such as heavy metals and salinity (Daneshbakhsh et al., 2013; Dražić et al., 2004; Khoshgoftar et al., 2004; Khoshgoftarmanesh, 2009). Concerning the concentration of $\mathrm{Cd}$ of the roots (32.18) and the shoots $\left(7.01 \mathrm{mg} \mathrm{g}^{-1} \mathrm{DW}\right)$ of noninoculated seedlings, a higher portion of the $\mathrm{Cd}$ taken up by wheat seedlings would remain in the roots rather than moving into shoots. This may be because of the cell wall polyanions and also accumulation of $\mathrm{Cd}$ in the vacuole of the root cells (Stolt, 2003). Liu et al., (2009) reported similar conclusion. They show that the accumulation of toxic heavy metals in winter wheat roots was significantly higher than in the aerial parts. Addition of Cd was most seen in the roots $(19.61 \%)$ and then in shoots $(9.27 \%)$ in noninoculated seedlings under salinity+Cd condition when compared to Cd-treated seedlings. Sodium chloride can increase the adverse effect of $\mathrm{Cd}$ via more mobilization of $\mathrm{Cd}$ in the soil solution and consequently more uptake of $\mathrm{Cd}$ by plant roots can happen (Khoshgoftar et al., 2004). In addition, $\mathrm{Fe}, \mathrm{Ca}$ and $\mathrm{K}$ of root in non-inoculated seedlings significantly decreased due to the excess of salinity and/or $\mathrm{Cd}$ in the root media. Therefore excessive $\mathrm{Cd}$ and/or salinity affects the rate of uptake and distribution of certain essential nutrients in plants, and consequently, this phenomena may be responsible for mineral deficiency/imbalance which causes limited plant growth. Uptake of $\mathrm{Cd}$ occurs via the same transmembrane carriers used to uptake $\mathrm{Ca}^{2+}$ and $\mathrm{Fe}^{2+}$, so addition of $\mathrm{Cd}$ can decrease the concentration of calcium and iron in plant (Dražić et al., 2004; Roth et al., 2006). Same conclusion reported by different researchers. Chang et al., (2012) found $\mathrm{Fe}^{2+}$ and $\mathrm{K}^{+}$content of root and shoot significantly decreased in Cdtreated rice seedlings. Also, Astolfi et al., (2012) showed that Fe deficiency enhanced in barley plants under excess of $\mathrm{Cd}$ availability.

Under saline condition, the competition between uptake of sodium and potassium by non-inoculated plants favored sodium ions, but potassium uptake was increased in the wheat seedlings inoculated with Azospirillum (Table 2). Inoculation improved harmful effects of $\mathrm{Cd}$ and/or salinity via less $\mathrm{Na}$ and hight $\mathrm{K}$ uptake and accumulation in the roots and shoots of inoculated plants. At the same time, less sodium entry into the cell and less potassium leakage out of the cell maybe happen. Reduction of sodium in the roots of inoculated seedlings may be the result of higher expression of TaSOS1 under excess of sodium.

PGPRs can affect the uptake of nutrient by changing root-uptake characteristics (Martinez-Toledo, 1991), and consequently change in relative growth rate (Rodelas et 
al., 1999; Tinker, 1984). We observed that A. brasilense could help to prevent sodium uptake by plant in inoculated wheat seedlings. It has been reported that production and secretion of bacterial exopolysaccharides to the root environment and in turn reducing the availability of $\mathrm{Na}^{+}$in the media is the cause of less $\mathrm{Na}$ uptake. This conclusion can be made on the basis of the result obtained by Upadhyay et al., (2011). They indicated that some of the native strains of bacteria which separated from the wheat rhizosphere of the soils were able to establish salt tolerance by bacterial secretion such as exopolysaccharides.

Lin et al., (1983) reported that inoculation of Zea and Sorghum bicolor roots with $A$. brasilense increased the uptake of several mineral ions such as $\mathrm{NO}^{3-}, \mathrm{K}^{+}$, and $\mathrm{H}_{2} \mathrm{PO}_{4}{ }^{-}$. Also, Chang et al., (2012) showed that $\mathrm{Cd}$ could decrease $\mathrm{Fe}$ and $\mathrm{K}^{+}$concentration, increase APX and CAT activity antioxidant enzymes and also improve Fe status which is able to reduce the toxicity of rice seedlings. Furthermore, the low iron content of plants that are grown under the high level of heavy metals generally shows chlorosis, since iron deficiency inhibits both chloroplast development and chlorophyll biosynthesis (Imsande, 1998).

The cell membrane plays an important role in metal homeostasis, via preventing or stimulation of nutrient passage into cell. $\mathrm{Cd}$ could alter the plasma membrane permeability by lipid peroxidation, reduction of ATPase activity (Fodor et al., 1995) and altering the activities of genes related to $\mathrm{Na}$ homeostasis. Our data showed $\mathrm{Cd}$ enhanced sodium of plant tissue (almost 24\%) and eventually, the TaSOS1 gene expression significantly increased to 14.3 fold change in Cd-treated seedlings compared to control plants. Our result show under saline condition, the competition between uptake of sodium and potassium by non-inoculated plants favored sodium ions (Wakeel, 2013; Tester and Davenport, 2003). Thus, antiporters of plant cell plasma membrane (SOS1) should be involved to maintain the plant cell ion homeostasis. Our results are consistent with Taherinia (2015), Ramezani et al., (2013) and Xu et al., (2008) who demonstrated salt stress could increase the relative TaSOS1 gene expression. In addition, we observed inoculation of seedlings with $A$. brasilense Sp7 can contribute to salt tolerate via overexpression of TaSOS1 gene. Although there is not any report related to the effects of A. brasilense on the upregulation of TaSOS1 in wheat seedlings, Vargas-Garcia et al. (2012) showed ethylene receptors genes expression in rice plants upregulated due to the inoculation with $A$. brasilense Sp245. There are some other reports relate to an increase in transcripts of some other genes involved in nutrient uptake in response to $A$. brasilense (Cavalcante, 2007; Kim, 2015; Nogueira, 2001).

Plant cell reduces the adverse effects of $\mathrm{Cd}$ through different mechanisms like secretion of organic acids (Nigam, 2001), using Casparian strip of the root plant cell (Lux, 2004), ABC transporters (Bovet et al., 2005; Verbruggen et al., 2009), antioxidant enzymes (Mishra, 2006) and expression of some genes which TaTM20 gene is one of them (Kim et al., 2008). So it is predictable that the TaTM20 gene expression for inhibition and detrimental effects to plant would be increased. Figure $4 b$ shows not only Cd increased the relative TaTM20 gene expression to 226.32 fold change but also an additive effect was observed in its expression under combined $\mathrm{Cd}+$ salinity (308.14 fold change). When we use manure containing $\mathrm{Cd}$ in agricultural land, especially under saline condition, potassium content of the root reduces because of chloride complexation of Cd (Ciećko, 2004; Smolders et al., 1998). Also, Kim et al., (2008) demonstrated $\mathrm{Cd}$ stress could increase the relative TaTM20 gene expression as well as Cd tolerance through the stimulation of Cd efflux from the cell. 
Under Cd+salinity stress, the relative TaTM20 gene expression in inoculated seedlings (188.36) was less than non-inoculated ones (308.14 fold change). Simultaneously we obtained better growth and less $\mathrm{Na}$ and higher potassium in the shoots and roots which indicated that inoculation provides a better condition for plant to grow. This result is in some ways similar to the result of Belimove and Dietz (2000) who showed that associative bacteria were capable of decreasing partially the toxicity of $\mathrm{Cd}$ for the barley plants through the improvement of nutrient uptake. Since the TaTM2O gene is known recently, so there is not enough information to present a good conclusion. However, it is possible that Azospirillum contributed to plants to tolerate the stress condition through the extension of the root system, secretion of exopolysaccharides and alteration of TaTM20 expression, which in turn decreasing the Cd uptake and its accumulation in the cytosol of a cell.

\section{Conclusion}

In non-inoculated condition, a reduction of $\mathrm{Fe}, \mathrm{Ca}, \mathrm{K}$ content and addition of $\mathrm{Na}, \mathrm{Cd}$, proline, antioxidant enzyme (CAT and APX), chlorophyll (a and b) and carotenoid in the root and shoot were observed under excess of $\mathrm{Cd}$. However, the changes in the measured indexes were higher for the excess of $\mathrm{Cd}$ under salinity. Losing of dry weight of roots and shoots was significantly correlated to measured indices. In excess of salinity or Cd, TaSOS1 expression was upregulated in the root of seedlings, and reached its maximum under dual effect of $\mathrm{Cd}$ and salinity (72.89 fold change). However, TaTM20 upregulation was more $\mathrm{Cd}$ dependent than salinity or inoculation but $\mathrm{Cd}$ had higher effect on TaTM20 upregulation under saline condition which might be because of more Cd solubility in the media.

Inoculation with $A$. brasilense improved root and shoot dry weight, caused more accumulation of $\mathrm{Fe}, \mathrm{Ca}$ and potassium but less uptake of $\mathrm{Cd}$ and $\mathrm{Na}$ in seedlings not exposed to $\mathrm{Cd}$ and salinity. Simultaneously, in inoculated seedlings there were less adverse effects on shoot's pigments such as chlorophyll a and carotenoid under excess of salinity and $\mathrm{Cd}$. These events coincided with upregulation of TaSOS1 under saline and/or Cd stress conditions.

Acknowledgements. Thanks to the University of Isfahan for financial support, and also thanks to the Department of Biology for cooperation and providing space and facilities. We also thank Dr. Manoochehr Tavassoli and Dr. Abolghasem Esmaeili for some gene expression explanation. Authors' contribution: Concept and design of study and finalizing the manuscript belongs to Akbar Mostajeran, layout and laboratory work as well as preparation of manuscript draft were obtained by Hamid-Reza Ghassemi and finally analysis and/or interpretation of data were made by all authors.

\section{REFERENCES}

[1] Adams, P. (1991): Effects of increasing the salinity of the nutrient solution with major nutrients or sodium chloride on the yield, quality and composition of tomatoes grown in rockwool. - Journal of Horticultural Science 66(2): 201-207.

[2] Alloway, B.J., Steinnes, E. (1999): Cadmium in Soils and Plants, eds. McLaughlin, M.J., Singh, B.R. Springer Netherlands, pp. 97-123. 
[3] Amooaghaie, R., Mostajeran, A., Emtiazi, G. (2002): The effect of compatible and incompatible Azospirillum brasilense strains on proton efflux of intact wheat roots. Plant and Soil 243(2): 155-160.

[4] Arnon, A. (1967): Method of extraction of chlorophyll in the plants. - Agron. J 23(112121.

[5] Asada, K. (2006): Production and scavenging of reactive oxygen species in chloroplasts and their functions. - Plant Physiology 141(2): 391-396.

[6] Askary, M., Mostajeran, A., Amooaghaei, R., Mostajeran, M. (2009): Influence of the coinoculation Azospirillum brasilense and Rhizobium meliloti plus 2, 4-D on grain yield and N, P, K content of Triticum aestivum (cv. Baccros and Mahdavi). - American-Eurasian Journal Agric. \& Environ. Sci 5(296-307.

[7] Astolfi, S., Zuchi, S., Neumann, G., Cesco, S., di Toppi, L., Pinton, R. (2012): Response of barley plants to Fe deficiency and $\mathrm{Cd}$ contamination as affected by $\mathrm{S}$ starvation. Journal of Experimental Botany 63(3): 1241-1250.

[8] Bashan, Y. (1990): Short exposure to Azospirillum brasilense Cd inoculation enhanced proton efflux of intact wheat roots. - Canadian Journal of Microbiology 36(6): 419-425.

[9] Bashan, Y., Bustillos, J.J., Leyva, L.A., Hernandez, J.-P., Bacilio, M. (2005): Increase in auxiliary photoprotective photosynthetic pigments in wheat seedlings induced by Azospirillum brasilense. - Biology and Fertility of Soils 42(4): 279-285.

[10] Bates, L., Waldren, R., Teare, I. (1973): Rapid determination of free proline for waterstress studies. - Plant and Soil 39(1): 205-207.

[11] Beers, R.F., Sizer, I.W. (1952): A spectrophotometric method for measuring the breakdown of hydrogen peroxide by catalase. - Journal of Biological Chemistry 195(1): 133-140.

[12] Belimov, A., Hontzeas, N., Safronova, V., Demchinskaya, S., Piluzza, G., Bullitta, S., Glick, B. (2005): Cadmium-tolerant plant growth-promoting bacteria associated with the roots of Indian mustard (Brassica juncea L. Czern.). - Soil Biology and Biochemistry 37(2): 241-250.

[13] Belimov, A.A., Dietz, K.-J. (2000): Effect of associative bacteria on element composition of barley seedlings grown in solution culture at toxic cadmium concentrations. Microbiological Research 155(2): 113-121.

[14] Bovet, L., Feller, U., Martinoia, E. (2005): Possible involvement of plant ABC transporters in cadmium detoxification: a cDNA sub-microarray approach. - Environment International 31(2): 263-267.

[15] Bradford, M.M. (1976): A rapid and sensitive method for the quantitation of microgram quantities of protein utilizing the principle of protein-dye binding. - Analytical Biochemistry 72(1-2): 248-254.

[16] Carillo, P., Mastrolonardo, G., Nacca, F., Parisi, D., Verlotta, A., Fuggi, A. (2008): Nitrogen metabolism in durum wheat under salinity: accumulation of proline and glycine betaine. - Functional Plant Biology 35(5): 412-426.

[17] Cavalcante, J., Vargas, C., Nogueira, E., Vinagre, F., Schwarcz, K., Baldani, J., Ferreira, P., Hemerly, A. (2007): Members of the ethylene signalling pathway are regulated in sugarcane during the association with nitrogen-fixing endophytic bacteria. - Journal of Experimental Botany 58(3): 673-686.

[18] Chang, Y.C., Chao, Y-Y., Kao, C.H. (2012): The role of iron in stress response to cadmium in rice seedlings. - Crop, Environment and Bioinformatics 9: 175-183.

[19] Cheng, Y.J., Kim, M.D., Deng, X.P., Kwak, S.S., Chen, W. (2013): Enhanced salt stress tolerance in transgenic potato plants expressing IbMYB1, a sweet potato transcription factor. - J. Microbiol. Biotechnol 23(12): 1737-1746.

[20] Cho, U.H., Seo, N.-H. (2005): Oxidative stress in Arabidopsis thaliana exposed to cadmium is due to hydrogen peroxide accumulation. - Plant Science 168(1): 113-120. 
[21] Ciećko, Z., Kalembasa, S., Wyszkowski, M., Rolka, E. (2004): Effect of soil contamination by cadmium on potassium uptake by plants. - Journal of Environmental Studies 13(3): 333-337.

[22] Corwin, D.L., Ahmad, H.R. (2015): Spatio-temporal impacts of dairy lagoon water reuse on soil: heavy metals and salinity. - Environ Sci Process Impacts 17(10): 1731-48.

[23] National Rerearch Council (1997): Toxicologic Assessment of the Army's Zinc Cadmium Sulfide Dispersion Tests. The National Academies Press, Washington, DC.

[24] Creus, C.M., Sueldo, R.J., Barassi, C.A. (1997): Shoot growth and water status in Azospirillum-inoculated wheat seedlings grown under osmotic and salt stresses. - PLANT Physiology and Biochemistry-Paris- 35: 939-944.

[25] Daneshbakhsh, B., Khoshgoftarmanesh, A.H., Shariatmadari, H., Cakmak, I. (2013): Phytosiderophore release by wheat genotypes differing in zinc deficiency tolerance grown with Zn-free nutrient solution as affected by salinity. - Journal of Plant Physiol 170(1): 41-46.

[26] Dell'Amico, E., Cavalca, L., Andreoni, V. (2008): Improvement of Brassica napus growth under cadmium stress by cadmium-resistant rhizobacteria. - Soil Biology and Biochemistry 40(1): 74-84.

[27] Dobermann, A. (2000): Rice: Nutrient disorders \& nutrient management. Int. Rice Res. Inst.

[28] Dražić, G., Mihailović, N., Stojanović, Z. (2004): Cadmium toxicity: The effect on macro-and micro-nutrient contents in soybean seedlings. - Biologia Plantarum 48(4): 605607.

[29] Ekmekçi, Y., Tanyolaç, D., Ayhan, B. (2008): Effects of cadmium on antioxidant enzyme and photosynthetic activities in leaves of two maize cultivars. - Journal of Plant Physiology 165(6): 600-611.

[30] El-Dengawy, E., Hussein, A.A., Alamri, S.A. (2011): Improving growth and salinity tolerance of carob seedlings (Ceratonia siliqua L.) by Azospirillum inoculation. - Am.Eurasian J. Agric. Environ. Sci. 11(3): 371-384.

[31] El-Hendawy, S.E., Hu, Y., Yakout, G.M., Awad, A.M., Hafiz, S.E., Schmidhalter, U. (2005): Evaluating salt tolerance of wheat genotypes using multiple parameters. European Journal of Agronomy 22(3): 243-253.

[32] Figueiredo, A.C., Barroso, J.G., Pedro, L.G., Scheffer, J.J. (2008): Factors affecting secondary metabolite production in plants: volatile components and essential oils. Flavour and Fragrance Journal 23(4): 213-226.

[33] Fodor, E., Szabó-Nagy, A., Erdei, L. (1995): The effects of cadmium on the fluidity and $\mathrm{H}^{+}$-ATPase activity of plasma membrane from sunflower and wheat roots. - Journal of Plant Physiology 147(1): 87-92.

[34] Fodor, F., Gáspár, L., Morales, F., Gogorcena, Y., Lucena, J.J., Cseh, E., Kröpfl, K., Abadía, J., Sárvári, É. (2005): Effects of two iron sources on iron and cadmium allocation in poplar (Populus alba) plants exposed to cadmium. - Tree Physiology 25(9): 11731180.

[35] Gao, Y., Miao, C., Wang, Y., Xia, J., Zhou, P. (2012): Metal-resistant microorganisms and metal chelators synergistically enhance the phytoremediation efficiency of Solanum nigrum L. in Cd-and Pb-contaminated soil. - Environmental Technology 33(12): 13831389.

[36] Giller, K.E., Witter, E., Mcgrath, S.P. (1998): Toxicity of heavy metals to microorganisms and microbial processes in agricultural soils: a review. - Soil Biology and Biochemistry 30(10): 1389-1414.

[37] Gohar, Z., Ahmad, R., Gul, H. (2003): Growth and development of cotton roots at various soil texture undersaline conditions. - Pakistan Journal of Botany 2(1): 12-19.

[38] Grant, C., Sheppard, S. (2008): Fertilizer impacts on cadmium availability in agricultural soils and crops. - Human and Ecological Risk Assessment 14(2): 210-228. 
[39] Hamdia, M.A.E.-S., Shaddad, M., Doaa, M.M. (2004): Mechanisms of salt tolerance and interactive effects of Azospirillum brasilense inoculation on maize cultivars grown under salt stress conditions. - Plant Growth Regulation 44(2): 165-174.

[40] He, Q.B., Singh, B.R. (1994): Crop uptake of cadmium from phosphorus fertilizers: I. Yield and cadmium content. - Water, Air, and Soil Pollution 74(3): 251-265.

[41] Heuer, B. (2010): Role of proline in plant response to drought and salinity. - Handbook of plant and crop stress. CRC Press, Boca Raton 213-238.

[42] Hoagland, D.R., Arnon, D.I. (1950): The water-culture method for the growing plants without soil. 347. - California Agricultural Experimental Station 347

[43] Imsande, J. (1998): Iron, sulfur, and chlorophyll deficiencies: a need for an integrative approach in plant physiology. - Physiologia Plantarum 103(1): 139-144.

[44] Jamil, A., Riaz, S., Ashraf, M., Foolad, M.R. (2011): Gene expression profiling of plants under salt stress. - Critical Reviews in Plant Sciences 30(5): 435-458.

[45] Kang, S.-M., Khan, A.L., Waqas, M., You, Y.-H., Kim, J.-H., Kim, J.-G., Hamayun, M., Lee, I.-J. (2014): Plant growth-promoting rhizobacteria reduce adverse effects of salinity and osmotic stress by regulating phytohormones and antioxidants in Cucumis sativus. Journal of Plant Interactions 9(1): 673-682.

[46] Khoshgoftar, A.H., Shariatmadari, H., Karimian, N., Kalbasi, M., van der Zee, S.E.A.T.M., Parker, D.R. (2004): Salinity and Zinc Application Effects on Phytoavailability of Cadmium and Zinc. - Soil Science Society of America Journal 68(6): 1885-1889.

[47] Khoshgoftarmanesh, A.H., Aghili, F., Sanaeiostovar, A. (2009): Daily intake of heavy metals and nitrate through greenhouse cucumber and bell pepper consumption and potential health risks for human. - International Journal of Food Sciences and Nutrition 60 Suppl 1:199-208.

[48] Kim, J.S., Lee, J., Seo, S.G., Lee, C., Woo, S.Y., Kim, S.H. (2015): Gene expression profile affected by volatiles of new plant growth promoting rhizobacteria, Bacillus subtilis strain JS, in tobacco. - Genes \& Genomics 37(4): 387-397.

[49] Kim, Y.Y., Kim, D.Y., Shim, D., Song, W.Y., Lee, J., Schroeder, J.I., Kim, S., Moran, N., Lee, Y. (2008): Expression of the novel wheat gene TM20 confers enhanced cadmium tolerance to bakers' yeast. - Journal of Biological Chemistry 283(23): 15893-15902.

[50] Brenner, D.J., Krieg N. R., Stanley, J.T., (2005): Genus Azospirillum. - Bergey's manual of systematic bacteriology, $2^{\text {th }}$ edition, volume two, 1:94-104.

[51] Leblebici, Z., Aksoy, A., Duman, F. (2011): Influence of salinity on the growth and heavy metal accumulation capacity of Spirodela polyrrhiza (Lemnaceae). - Turkish journal of biology 35(2): 215-220.

[52] Lin, C.C., Kao, C.H. (2001): Cell wall peroxidase activity, hydrogen peroxide level and $\mathrm{NaCl}$-inhibited root growth of rice seedlings. - Plant and Soil 230(1): 135-143.

[53] Lin, W., Okon, Y., Hardy, R.W. (1983): Enhanced mineral uptake by Zea mays and Sorghum bicolor roots inoculated with Azospirillum brasilense. - Applied and Environmental Microbiology 45(6): 1775-1779.

[54] Liu, D., Wang, M., Zou, J., Jiang, W. (2006): Uptake and accumulation of cadmium and some nutrient ions by roots and shoots of maize (Zea mays L.). - Pakistan Journal of Botany 38(3): 701.

[55] Liu, W.X., Liu, J.W., Wu, M.Z., Li, Y., Zhao, Y., Li, S.R. (2009): Accumulation and translocation of toxic heavy metals in winter wheat (Triticum aestivum L.) growing in agricultural soil of Zhengzhou, China. - Bulletin of Environmental Contamination and Toxicology 82(3): 343-347.

[56] Livak, K.J., Schmittgen, T.D. (2001): Analysis of relative gene expression data using real-time quantitative PCR and the $2^{-\Delta \Delta C T}$ method. - Methods 25(4): 402-408.

[57] Lux, A., Martinka, M., Vaculík, M., White, P.J. (2011): Root responses to cadmium in the rhizosphere: a review. - Journal of Experimental Botany 62(1): 21-37. 
[58] Lux, A., Šottníková, A., Opatrná, J., Greger, M. (2004): Differences in structure of adventitious roots in Salix clones with contrasting characteristics of cadmium accumulation and sensitivity. - Physiologia Plantarum 120(4): 537-545.

[59] Ma, Y., Rajkumar, M., Freitas, H. (2009): Inoculation of plant growth promoting bacterium Achromobacter xylosoxidans strain Ax10 for the improvement of copper phytoextraction by Brassica juncea. - Journal of Environmental Management 90(2): 831837.

[60] Mahajan, S., Tuteja, N. (2005): Cold, salinity and drought stresses: an overview. Archives of Biochemistry and Biophysics 444(2): 139-58.

[61] Martinez-Toledo, M., Salmerón, V., González-López, J. (1991): Biological characteristics of Azotobacter spp. in natural environments. - Trends Soil Sci 1: 15-23.

[62] Matysik, J., Alia, Bhalu, B., Mohanty, P. (2002): Molecular mechanisms of quenching of reactive oxygen species by proline under stress in plants. - Current Science 525-532.

[63] Mishra, S., Srivastava, S., Tripathi, R., Govindarajan, R., Kuriakose, S., Prasad, M. (2006): Phytochelatin synthesis and response of antioxidants during cadmium stress in Bacopa monnieri L. - Plant Physiology and Biochemistry 44(1): 25-37.

[64] Nakano, Y., Asada, K. (1981): Hydrogen peroxide is scavenged by ascorbate-specific peroxidase in spinach chloroplasts. - Plant and Cell Physiology 22(5): 867-880.

[65] Nellemann, C. (2009): The environmental food crisis: the environment's role in averting future food crises: a UNEP rapid response assessment. UNEP/Earthprint.

[66] Neumann, P.M. (1995): The role of cell wall adjustments in plant resistance to water deficits. - Crop Science 35(5): 1258-1266.

[67] Nigam, R., Srivastava, S., Prakash, S., Srivastava, M. (2001): Cadmium mobilisation and plant availability-the impact of organic acids commonly exuded from roots. - Plant and Soil 230(1): 107-113.

[68] Nogueira, E.d.M., Vinagre, F., Masuda, H.P., Vargas, C., Pádua, V.L.M.d., Silva, F.R.d., Santos, R.V.d., Baldani, J.I., Ferreira, P.C.G., Hemerly, A.S. (2001): Expression of sugarcane genes induced by inoculation with Gluconacetobacter diazotrophicus and Herbaspirillum rubrisubalbicans. - Genetics and Molecular Biology 24(1-4): 199-206.

[69] Nriagu, J.O., Sprague, J.B. (1987): Cadmium in the aquatic environment. -.

[70] Omar, M.N.A., Osman, M.E.H., Kasim, W.A., Abd El-Daim, I.A. (2009): Salinity and water Stress: Improving Crop Efficiency, eds. Ashraf, M., Ozturk, M., Athar, H.R. Springer Netherlands, Dordrecht, pp. 133-147.

[71] Othman, N.F.H. (2015): Effects of ACC deaminase activity of Azospirillum Brasilense (Sp7) and Escherichia Coli (L2) on growth of rice seedlings. Pp 152

[72] Pakdaman, N., Ghaderian, S.M., Ghasemi, R., Asemaneh, T. (2013): Effects of calcium/magnesium quotients and nickel in the growth medium on growth and nickel accumulation in Pistacia atlantica. - Journal of Plant Nutrition 36(11): 1708-1718.

[73] Parida, A., Das, A., Mittra, B. (2003): Effects of NaCl stress on the structure, pigment complex composition, and photosynthetic activity of mangrove Bruguiera parviflora chloroplasts. - Photosynthetica 41(2): 191-200.

[74] Pessarakli, M., Huber, J. (1991): Biomass production and protein synthesis by alfalfa under salt stress. - Journal of Plant Nutrition 14(3): 283-293.

[75] Prapagdee, B., Khonsue, N. (2015): Bacterial-assisted cadmium phytoremediation by Ocimum gratissimum L. in polluted agricultural soil: a field trial experiment. International Journal of Environmental Science and Technology 12(12): 3843-3852.

[76] Ramezani, A., Niazi, A., Abolimoghadam, A.A., Babgohari, M.Z., Deihimi, T., Ebrahimi, M., Akhtardanesh, H., Ebrahimie, E. (2013): Quantitative expression analysis of TaSOS1 and TaSOS4 genes in cultivated and wild wheat plants under salt stress. - Molecular Biotechnology 53(2): 189-197.

[77] Rodelas, B., González-López, J., Pozo, C., Salmerón, V., Martínez-Toledo, M.V. (1999): Response of Faba bean (Vicia faba L.) to combined inoculation with Azotobacter and Rhizobium leguminosarum bv. viceae. - Applied Soil Ecology 12(1): 51-59. 
[78] Roth, U., von Roepenack-Lahaye, E., Clemens, S. (2006): Proteome changes in Arabidopsis thaliana roots upon exposure to $\mathrm{Cd}^{2+}$. - Journal of Experimental Botany 57(15): 4003-4013.

[79] Sauer, D., Burroughs, R. (1986): Disinfection of seed surfaces with sodium hypochlorite. - Phytopathology 76(7): 745-749.

[80] Shafi, M., Bakht, J., Hassan, M.J., Raziuddin, M., Zhang, G. (2009): Effect of cadmium and salinity stresses on growth and antioxidant enzyme activities of wheat (Triticum aestivum L.). - Bulletin of Environmental Contamination and Toxicology 82(6): 772-776.

[81] Shah, S.S., Mohammad, F., Shafi, M., Bakht, J., Zhou, W. (2011): Effects of cadmium and salinity on growth and photosynthesis parameters of Brassica species. - Pakistan Journal of Botany 43(1): 333-340.

[82] Sharmila, P., Kumari, P.K., Singh, K., Prasad, N.V.S.R.K., Pardha-Saradhi, P. (2017): Cadmium toxicity-induced proline accumulation is coupled to iron depletion. Protoplasma 254(2): 763-770.

[83] Sheppard, S., Grant, C., Sheppard, M., De Jong, R., Long, J. (2009): Risk indicator for agricultural inputs of trace elements to canadian soils all rights reserved. No part of this periodical may be reproduced or transmitted in any form or by any means, electronic or mechanical, including photocopying, recording, or any information storage and retrieval system, without permission in writing from the publisher. - Journal of Environmental Quality 38(3): 919-932.

[84] Siadat, H. (1998): Proceeding of the Conference on New Technologies to Combat Desertification. pp. 12-15.

[85] Skoog, D., West, D., Holler, F., Crouch, S. (2005): Flame photometric determination of sodium. - Analytic Chemistry: An Introduction. Edition 7:594-631.

[86] Smolders, E., Lambregts, R.M., McLaughlin, M.J., Tiller, K.G. (1998): Effect of soil solution chloride on cadmium availability to Swiss chard. - Journal of Environmental Quality 27(2): 426-431.

[87] Stobart, A.K., Griffiths, W.T., Ameen-Bukhari, I., Sherwood, R.P. (1985): The effect of $\mathrm{Cd}^{2+}$ on the biosynthesis of chlorophyll in leaves of barley. - Physiologia Plantarum 63(3): 293-298.

[88] Stolt, J.P., Sneller, F.E.C., Bryngelsson, T., Lundborg, T., Schat, H. (2003): Phytochelatin and cadmium accumulation in wheat. - Environmental and Experimental Botany 49(1): 21-28.

[89] Stout, L.M., Dodova, E.N., Tyson, J.F., Nüsslein, K. (2010): Phytoprotective influence of bacteria on growth and cadmium accumulation in the aquatic plant Lemna minor. - Water Research 44(17): 4970-4979.

[90] Taherinia, B., Kavousi, H.R., Dehghan, S. (2015): Isolation and characterization of plasma membrane $\mathrm{Na}^{+} / \mathrm{H}^{+}$antiporter (SOSl) gene during salinity stress in kallar grass (Leptochloa fusca). - EurAsian Journal of BioSciences 9:12-20.

[91] Tavakoli, M., Poustini, K., Alizadeh, H. (2016): Proline accumulation and related genes in wheat leaves under salinity stress. - Journal of Agricultural Science and Technology 18(3): 707-716.

[92] Tester, M., Davenport, R. (2003): $\mathrm{Na}^{+}$tolerance and $\mathrm{Na}^{+}$transport in higher plants. - Ann Bot. 91(5):503-27.

[93] Tinker, P. (1984): The role of microorganisms in mediating and facilitating the uptake of plant nutrients from soil. - Plant and Soil 76(1-3): 77-91.

[94] Tiwari, J.K., Munshi, A.D., Kumar, R., Pandey, R.N., Arora, A., Bhat, J.S., Sureja, A.K. (2010): Effect of salt stress on cucumber: $\mathrm{Na}^{+} / \mathrm{K}^{+}$ratio, osmolyte concentration, phenols and chlorophyll content. - Acta Physiologiae Plantarum 32(1): 103-114.

[95] Upadhyay, S.K., Singh, J.S., Singh, D.P. (2011): Exopolysaccharide-producing plant growth-promoting rhizobacteria under salinity condition. - Pedosphere 21(2): 214-222. 
[96] Vargas-Garcia Mdel, C., Lopez, M.J., Suarez-Estrella, F., Moreno, J. (2012): Compost as a source of microbial isolates for the bioremediation of heavy metals: in vitro selection. Science of the Total Environment 431: 62-67.

[97] Vargas, L., de Carvalho, T.L.G., Ferreira, P.C.G., Baldani, V.L.D., Baldani, J.I., Hemerly, A.S. (2012): Early responses of rice (Oryza sativa L.) seedlings to inoculation with beneficial diazotrophic bacteria are dependent on plant and bacterial genotypes. Plant and Soil 356(1): 127-137.

[98] Verbruggen, N., Hermans, C., Schat, H. (2009): Mechanisms to cope with arsenic or cadmium excess in plants. - Current Opinion in Plant Biology 12(3): 364-372.

[99] Vodyanitskii, Y.N. (2016): Standards for the contents of heavy metals in soils of some states. - Annals of Agrarian Science 14(3): 257-263.

[100] Wakeel, A. (2013): Potassium-sodium interactions in soil and plant under saline-sodic conditions. - Journal of Plant Nutrition and Soil Science 176(3): 344-354.

[101] Wallace, A., Wallace, G., Cha, J. (1992): Some modifications in trace metal toxicities and deficiencies in plants resulting from interactions with other elements and chelating agents-the special case of iron. - Journal of Plant Nutrition 15(10): 1589-1598.

[102] Wani, P.A., Khan, M.S. (2010): Bacillus species enhance growth parameters of chickpea (Cicer arietinum L.) in chromium stressed soils. - Food and Chemical Toxicology 48(11): 3262-3267.

[103] Weggler-Beaton, K., McLaughlin, M.J., Graham, R. (2000): Salinity increases cadmium uptake by wheat and Swiss chard from soil amended with biosolids. - Soil Research 38(1): 37-46.

[104] Xu, H., Jiang, X., Zhan, K., Cheng, X., Chen, X., Pardo, J.M., Cui, D. (2008): Functional characterization of a wheat plasma membrane $\mathrm{Na}^{+} / \mathrm{H}^{+}$antiporter in yeast. - Archives of Biochemistry and Biophysics 473(1): 8-15.

[105] Yadav, S., Chandra, R. (2013): Effect of heavy metals and phenol on bacterial decolourisation and COD reduction of sucrose-aspartic acid Maillard product. - Journal of Environmental Sciences (China) 25(1): 172-80.

[106] Yamaguchi, H., Fukuoka, H., Arao, T., Ohyama, A., Nunome, T., Miyatake, K., Negoro, S. (2009): Gene expression analysis in cadmium-stressed roots of a low cadmiumaccumulating solanaceous plant, Solanum torvum. - Journal of Experimental Botany 61(2): 423-437.

[107] Zhang, H., Kim, M.-S., Sun, Y., Dowd, S.E., Shi, H., Paré, P.W. (2008a): Soil bacteria confer plant salt tolerance by tissue-specific regulation of the sodium transporter HKT1. Molecular Plant-Microbe Interactions 21(6): 737-744.

[108] Zhang, H., Xie, X., Kim, M.-S., Kornyeyev, D.A., Holaday, S., Paré, P.W. (2008b): Soil bacteria augment Arabidopsis photosynthesis by decreasing glucose sensing and abscisic acid levels in planta. - The Plant Journal 56(2): 264-273. 